\title{
Statistical design and optimization of nutritional value production by an oleaginous yeast Yarrowia lipolytica cultured in industrial - waste molasses
}

\author{
Benjamaporn Wonganu ${ }^{1,2^{*}}$, Sasithorn Kongruang ${ }^{l}$, and Ratiya Charoensakdi ${ }^{1}$ \\ ${ }^{1}$ Department of Biotechnology, Faculty of Applied Science King Mongkut's University of Technology North \\ Bangkok Bangkok, Thailand \\ ${ }^{2}$ Biorefinery and Process Automation Engineering Center King Mongkut's University of Technology North \\ Bangkok Bangkok, Thailand
}

\begin{abstract}
Abundant by-products from sugar mills as industrial-waste molasses can be used as a carbon source in yeast culture media. Yarrowia lipolytica is an interesting yeast used as a candidate for cultivation in molasses medium. Here, we used response surface methodology to derive a statistical model for the individual and interactive effects of $\mathrm{pH}$, temperature, and shaking speeds on the production of yeast cells. Cultivation conditions of yeast were optimized using Design Expert based on a $2^{3}$ factorial central composite design (CCD) for maximum yeast cell production. Optimal conditions for maximum $Y$. lipolytica 5151 cell masses were as follows: $\mathrm{pH}, 6.45$; temperature, $30^{\circ} \mathrm{C}$; Shaking speed, $165 \mathrm{rpm}$. The Design Expert represented the maximal numerical solution with a predicted cell mass production level at $8.96 \mathrm{~g} / \mathrm{L}$. The experimental production of $Y$. lipolytica 5151 cell mass yielded $8.27 \mathrm{~g} / \mathrm{L}$ that is $7.67 \%$ deviated from the model. Whereas, the model of TISTR 5621 was not adequate for prediction. Yeasts cultured under statistic prediction provide $55.94 \%$ and $51.25 \%$ of total protein. Amino acid content and vitamin B1 (1.06 mg and $1.47 \mathrm{mg}$ per $100 \mathrm{~g}$ of dried $Y$. lipolytica 5151 and 5621 , respectively) provided the relevant information for an alternative supplement in aquatic feed.
\end{abstract}

Keyword. Molasses; An oleaginous yeast; statistic design

\section{Introduction}

Yarrowia lipolytica is classified as an oleaginous yeast that has a high ability to produce lipids or triacylglycerides (TAGs) depended on a culture condition. It becomes to be an attractive alternative source to decrease the dependency on vegetable and mineral oil. Moreover, it was used as a non-pathogenic microorganism for lipid production applied as components in coatings, paints, personal care products, production of fine chemicals, and biodiesel [1]. $Y$. lipolytica can produce and accumulate $30-43 \%$ lipid in the cell, and it also can produce and secret a high level of protein $[2,3]$.

A study in a yeast species known as saccharomyces cerevisiae as a nutritional yeast containing protein, vitamins, minerals, and antioxidants. However, the composition and nutritive value of $Y$. lipolytica biomass are still limited. Due to the ability to secrete protein at a high level depending on the carbon source in contrast to $S$. cerevisiae, $Y$. lipolytica has become the most interesting organism for many applications in producing and secretion of several organic acids and fragrances. $[4,5]$

The development of an economic culture medium for $Y$. lipolytica needs to obtain a high quantity of its biomass. The satisfied medium must compose of the basic requirements for cell biomass. The carbon substrate is a main role in biosynthesis and energy generation [6]. There are various carbon sources in microbial culture. Since $Y$. lipolytica can use unusual carbon sources, such as hydrocarbons, several studies focused on increasing yeast biomass by using different carbon sources. Juszczyk et al. [7] used waste derived from the production of ethyl esters of polyunsaturated fatty acids of flaxseed oil to produce biomass of $Y$. lipolytica. Wrobel-Kwiatkowska et al. [8] developed $Y$. lipolytica media containing different kinds of honey for product improvement of Kynurenic acid. Media development for $Y$. lipolytica growth is relevant because media cost is a significant problem of the large-scale yeast cultivation for industrial applications. Therefore, Molasses is a by-product of sugar processing, and it also can be an efficient, low-cost carbon source in a $Y$. lipolytica culture.

\footnotetext{
* Corresponding author: Benjamaporn.w@sci.kmutnb.ac.th
} 
The response surface methodology (RSM) is a mathematical and statistical technique to estimate the experimental variability, confirm the adequacy between the proposed model and the experimental data, predict the observed response and construct the results in a $3 \mathrm{D}$ empirical model [9]. Due to the tedious task of the classical "one-factor-at-a-time" method in investigating interactions between variables, RSM method has been applied in biological research, food, and feed technology applications. This study aims to optimize the best conditions for $Y$. lipolytica TISTR 5151 and 5621 to grow in industrial-waste molasses using the Design expert program. $Y$. lipolytica could be an alternative source or ingredient for fish and shrimp feeds.

\section{Materials and Methods}

\subsection{Materials}

Y. lipolytica TISTR 5151 and 5621 were purchased from Thailand Institute of Scientific and Technological Research (TISTR), Thailand. Peptone, Yeast extract, Malt extract, Agar, Hydrochloric acid, Sodium hydroxide used for cell culture and analysis were of analytical grade. They were purchased from Sigma, USA, and HiMedia, India. Molasses was supported by a local sugar factory in Suphanburi province, Thailand. Design Expert ver. 10.0.2 was used in the optimization analysis of the yeast cell growth.

\subsection{Yeast cells preparations}

Y. lipolytica TISTR 5151 and 5621 were grown on modified media composed of $5.6 \%$ molasses as a carbon source, $0.5 \%$ peptone, $0.3 \%$ yeast extract, and $0.3 \%$ malt extract. The yeasts were cultured in three various optimized factors ( $\mathrm{pH}$, temperature, and shaking speed). Moisture contents from a moisture analyzer were relative to yeast cell dry weight values, as the following equation shows below [10].

$$
\% \text { Moisture content }=\frac{\text { Initial weight }(\mathrm{g})-\text { Final weight }(\mathrm{g})}{\text { Initial weight of sample }(\mathrm{g})}
$$

\subsection{Experimental Design setup for yeast cell growth optimization}

In the research, three selected factors were $\mathrm{pH}$, temperature, and shaking speed. These factors were used to determine their effects on two strains of yeast cell growth in the modified culture medium containing molasses as a carbon source. The experiments used a central composite design. Table 1 shows the factors and their levels where the high level indicates the highest range of the factors, and the low level reveals the lowest of the factors. Experiment design Tables 2 and 3 of $Y$. lipolytica TISTR 5151 and 5621 were constructed using the Design Expert Software v.10.0.2, and the experiment data was analyzed using the same software.

\subsection{Nutritional value analysis of dry yeasts.}

Free amino acid contents and vitamin B1 were determined from each yeast cells. HPLC technique was applied to the quantification of each amino acid and vitamin $\mathrm{B} 1$ of $100 \mathrm{~g}$ of each dry yeast $[11,12]$.
Table 1. The levels of selected factors

\begin{tabular}{ccc}
\hline Factors & Low level & High level \\
\hline $\mathrm{pH}$ & 5 & 9 \\
Temperature (Celsius) & 28 & 32 \\
Shaking speed (rpm) & 150 & 250 \\
\hline
\end{tabular}

Table 2. Experimental setup of $Y$. lipolytica TISTR 5151 that has been constructed by using $2^{3}$ factorial analyses by Design Expert software v.10.0.2

\begin{tabular}{|c|c|c|c|}
\hline Run & $\begin{array}{c}\text { Factor1 } \\
\text { A: } \mathrm{pH}\end{array}$ & $\begin{array}{c}\text { Factor2 } \\
\text { B: temperature } \\
\text { (Celsius) }\end{array}$ & $\begin{array}{c}\text { Factor3 } \\
\text { C: Shaking speed } \\
\text { (rpm) }\end{array}$ \\
\hline 1 & 7 & 30 & 200 \\
2 & 7 & 30 & 200 \\
3 & 7 & 28 & 200 \\
4 & 7 & 30 & 200 \\
5 & 9 & 28 & 250 \\
6 & 9 & 32 & 250 \\
7 & 7 & 30 & 150 \\
8 & 5 & 30 & 200 \\
9 & 5 & 28 & 150 \\
10 & 9 & 28 & 150 \\
11 & 7 & 30 & 200 \\
12 & 9 & 30 & 200 \\
13 & 5 & 32 & 250 \\
14 & 7 & 30 & 200 \\
15 & 7 & 30 & 200 \\
16 & 7 & 30 & 250 \\
17 & 7 & 32 & 200 \\
18 & 5 & 32 & 150 \\
19 & 5 & 28 & 250 \\
20 & 9 & 32 & 150 \\
\hline
\end{tabular}

Table 3. Experimental setup of $Y$. lipolytica TISTR 5621 that has been constructed by using $2^{3}$ factorial analyses by Design Expert software v.10.0.2

\begin{tabular}{|c|c|c|c|}
\hline Run & $\begin{array}{c}\text { Factor } 1 \\
\text { A: } \mathrm{pH}\end{array}$ & $\begin{array}{c}\text { Factor2 } \\
\text { B: temperature } \\
\text { (Celsius) }\end{array}$ & $\begin{array}{c}\text { Factor3 } \\
\text { C: Shaking } \\
\text { speed } \\
\text { (rpm) }\end{array}$ \\
\hline 1 & & 30 & 200 \\
2 & 7 & 30 & 200 \\
3 & 7 & 32 & 200 \\
4 & 7 & 32 & 150 \\
5 & 5 & 30 & 200 \\
6 & 7 & 28 & 250 \\
7 & 9 & 30 & 150 \\
8 & 7 & 30 & 200 \\
9 & 9 & 28 & 200 \\
10 & 7 & 30 & 200 \\
11 & 7 & 32 & 150 \\
12 & 9 & 30 & 200 \\
13 & 7 & 32 & 250 \\
14 & 5 & 30 & 250 \\
15 & 7 & 28 & 250 \\
16 & 5 & 30 & 200 \\
17 & 5 & 28 & 150 \\
18 & 5 & 32 & 250 \\
19 & 9 & 30 & 200 \\
20 & 7 & 28 & 150 \\
\hline
\end{tabular}




\section{Results and discussions}

3.1 Screening of Factors Affecting on $Y$. lipolytica TISTR 5151 and 5621 Growth

$\mathrm{pH}$, temperature, and shaking speed were applied to study the practical effect on yeast growth. $2^{3}$ level factorial method in Design Expert was used to optimize the condition to obtain the highest biomass yields. Tables 4 and 5 show 20 runs of experiments that reveal obtained yeast cell dry weight results. The response was analyzed using the ANOVA component of central composite design (CCD) found in response surface methodology of the Design-Expert software v10.0.2 at $95 \%$ confidence level. For $Y$. lipolytica TISTR 5151, the highest yield of biomass was obtained at $\mathrm{pH} 7,30^{\circ} \mathrm{C}$, and $200 \mathrm{rpm}$ of shaking speed, whereas the condition for the highest yield of biomass of Y. lipolytica TISTR 5621 at $\mathrm{pH} 5,32^{\circ} \mathrm{C}$, and $150 \mathrm{rpm}$ of shaking speed. The design matrix for CCD experiments and the experiment results and the predicted responses for Cell Dry Weight (CDW) of Y. lipolytica TISTR 5151 and 5621 were regressed using a quadratic polynomial equation and linear equation for TISTR 5151 and 5621, respectively. The two regression equations were as follows:

CDW of Y.lipolytica TISTR $5151=$ $-23.12384-0.22690 \mathrm{~A}+1.64501 \mathrm{~B}-0.00191783 \mathrm{C}+$ $0.010257 \mathrm{AB}-0.000289708 \mathrm{AC}+(0.000239625 \mathrm{BC}-$ $0.00205265 \mathrm{~A}^{2}-0.028965 \mathrm{~B}^{2}-0.00000947090 \mathrm{C}^{2}$

\section{CDW of Y. lipolytica TISTR $5621=0.75398-$} $0.00282833 \mathrm{~A}+0.00377 \mathrm{~B}-0.0003456 \mathrm{C}$

where $\mathrm{A}$ is $\mathrm{pH}, \mathrm{B}$ is the temperature (Celsius), and $\mathrm{C}$ is shaking speed (rpm)

Table 4. Experimental results of $Y$. lipolytica TISTR 5151 cell dry weight on different factors using Design Expert software v.10.0.2 based on $2^{3}$ level factorial CCD

\begin{tabular}{|c|c|c|c|c|}
\hline Run & $\begin{array}{c}\text { Factor1 } \\
\text { A: pH }\end{array}$ & $\begin{array}{c}\text { Factor2 } \\
\text { B: } \\
\text { Temperature } \\
\text { (Celsius) }\end{array}$ & $\begin{array}{c}\text { Factor3 } \\
\text { C= Shaking } \\
\text { speed } \\
\text { (rpm) }\end{array}$ & $\begin{array}{c}\text { Response } \\
\text { Cell Dry } \\
\text { Weight } \\
(\mathrm{CDW}) \\
(10 \mathrm{~g} / \mathrm{L})\end{array}$ \\
\hline 1 & 7 & 30 & 200 & 0.891 \\
2 & 7 & 30 & 200 & 0.891 \\
3 & 7 & 28 & 200 & 0.721 \\
4 & 7 & 30 & 200 & 0.891 \\
5 & 9 & 28 & 250 & 0.504 \\
6 & 9 & 32 & 250 & 0.828 \\
7 & 7 & 30 & 150 & 0.876 \\
8 & 5 & 30 & 200 & 0.877 \\
9 & 5 & 28 & 150 & 0.733 \\
10 & 9 & 28 & 150 & 0.764 \\
11 & 7 & 30 & 200 & 0.896 \\
12 & 9 & 30 & 200 & 0.895 \\
13 & 5 & 32 & 250 & 0.748 \\
14 & 7 & 30 & 200 & 0.891 \\
15 & 7 & 30 & 200 & 0.891 \\
16 & 7 & 30 & 250 & 0.865 \\
17 & 7 & 32 & 200 & 0.837 \\
18 & 5 & 32 & 150 & 0.797 \\
19 & 5 & 28 & 250 & 0.767 \\
20 & 9 & 32 & 150 & 0.814 \\
\hline
\end{tabular}

Table 5. Experimental results of $Y$. lipolytica TISTR 5621 cell dry weight on different factors using Design Expert software v.10.0.2 based on $2^{3}$ level factorial CCD.

\begin{tabular}{|c|c|c|c|c|}
\hline Run & $\begin{array}{c}\text { Factor1 } \\
\text { A:pH }\end{array}$ & $\begin{array}{c}\text { Factor2 } \\
\text { B:Temperature } \\
\text { (Celsius) }\end{array}$ & $\begin{array}{c}\text { Factor3 } \\
\text { C= } \\
\text { Shaking } \\
\text { speed } \\
\text { (rpm) }\end{array}$ & $\begin{array}{c}\text { Response } \\
\text { Cell Dry } \\
\text { Weight } \\
(\mathrm{CDW}) \\
(10 \mathrm{~g} / \mathrm{L})\end{array}$ \\
\hline 1 & 7 & 30 & 200 & 0.765 \\
2 & 7 & 30 & 200 & 0.765 \\
3 & 7 & 32 & 200 & 0.746 \\
4 & 5 & 32 & 150 & 0.845 \\
5 & 7 & 30 & 200 & 0.765 \\
6 & 9 & 28 & 250 & 0.695 \\
7 & 7 & 30 & 150 & 0.771 \\
8 & 9 & 30 & 200 & 0.784 \\
9 & 7 & 28 & 200 & 0.824 \\
10 & 7 & 30 & 200 & 0.765 \\
11 & 9 & 32 & 150 & 0.842 \\
12 & 7 & 30 & 200 & 0.765 \\
13 & 5 & 32 & 250 & 0.784 \\
14 & 7 & 30 & 250 & 0.813 \\
15 & 5 & 28 & 250 & 0.799 \\
16 & 5 & 30 & 200 & 0.732 \\
17 & 5 & 28 & 150 & 0.787 \\
18 & 9 & 32 & 250 & 0.766 \\
19 & 7 & 30 & 200 & 0.764 \\
20 & 9 & 28 & 150 & 0.794 \\
\hline
\end{tabular}

3.2 Analysis of Variance (ANOVA) for yeast cell dry weight

The analysis of variance (ANOVA) for the CCD experiment was performed to estimate the coefficient of the model and determine the significance of each parameter (Table 6). The F-values and P-values were used to identify the effect of each factor on obtained cell dry weight in each strain of $Y$. lipolytica. The model of $Y$. lipolytica TISTR 5151 exhibited correlation with the experimental data with high $\mathrm{F}$-value and $\mathrm{P}$-value $<0.05$, which implied the significance of the model. In contrast, low F-value and $\mathrm{P}>0.05$ of $Y$. lipolytica TISTR 5621 model indicated that this model was not significant. By inspecting each $\mathrm{F}$-values and $\mathrm{P}$-values of the $\mathrm{Y}$. lipolytica TISTR 5151 model, it can be seen that the effect on biomass of Y. lipolytica cultured in media containing molasses carbon source depended on the temperature. Different strains in $Y$. lipotica had various physiological and metabolism properties and required other conditions to grow.

The previous studies were found that high temperature affects sugar alcohol production [13]. In TISTR 5151, $\mathrm{R}^{2}$ value $(0.90)$ indicated that the model was reliable for predicting biomass. The lack of fit Fvalue which was 1.87 (P-value $0.1577<0.05$ ), also replied that the model was adequate for prediction.

Three-dimensional response surface plots were constructed to show the effect of $\mathrm{pH}$, temperature and shaking speed on cell dry weight of $Y$. lipolytica TISTR 5151 (Figure 1). The impact of individual variables is paired within the experiment range. This graphical visualization allows investigating the relationships between the experimental levels of each factor and the response. There was a large interactive effect of 
temperature and another factor on cell dry weight. At moderate temperature, the strongest yeast biomass increases $Y$. lipolytica TISTR 5151 cultured in the media containing molasses as a carbon source. When dry cell weight was considered, the interactions between $\mathrm{pH}$ and temperature and the interaction between shaking speed and temperature are strong (Figure $1 \mathrm{~A}$ and $1 \mathrm{C}$ ). In contrast, it is not been shown in the interaction between shaking speed and $\mathrm{pH}$ (Figure 1C).
The optimal levels of those factors can be deduced from a 3D response and the equation obtained from regression analysis. The model predicted that the maximum cell dry weight $(8.96 \mathrm{~g} / \mathrm{mL})$ was located at $\mathrm{A}=$ $6.45, \mathrm{~B}=30$ Celsius, and $\mathrm{C}=165 \mathrm{rpm}$. The experiments were performed in the predicted cell culture condition to examine the validity of this model. The average obtained biomass was $8.27 \mathrm{~g} / \mathrm{L}$. It was close to the predicted values and supported the suitability of the model in this study.

Table 6. Analysis of variance (ANOVA) for the experimental results of the CCD

\begin{tabular}{|c|c|c|c|c|c|c|c|c|c|c|}
\hline Source & \multicolumn{5}{|c|}{ Y. lipolytica TISTR 5151} & \multicolumn{5}{|c|}{ Y. lipolytica TISTR 5621} \\
\hline & SS & $\mathrm{df}$ & SM & F-value & $\mathrm{P}$-value & SS & $\mathrm{df}$ & SM & $\begin{array}{c}\text { F- } \\
\text { value }\end{array}$ & P-value \\
\hline Model & 0.16 & 9 & 0.017 & 9.43 & 0.0008 & 0.0039 & 3 & 0.0013 & 1.09 & 0.3815 \\
\hline $\mathrm{A}$ & 0.0042 & 1 & 0.0043 & 2.33 & 0.1577 & 0.00032 & 1 & 0.00032 & 0.27 & 0.6103 \\
\hline B & 0.033 & 1 & 0.033 & 17.80 & 0.0018 & 0.00057 & 1 & 0.00057 & 0.48 & 0.4983 \\
\hline $\mathrm{C}$ & 0.00017 & 1 & 0.00017 & 0.0094 & 0.7650 & 0.00298 & 1 & 0.00298 & 2.52 & 0.1319 \\
\hline $\mathrm{AB}$ & 0.013 & 1 & 0.013 & 7.33 & 0.0221 & - & - & - & - & \\
\hline $\mathrm{AC}$ & 0.0067 & 1 & 0.0067 & 3.65 & 0.0850 & - & - & - & - & - \\
\hline $\mathrm{BC}$ & 0.0046 & 1 & 0.0046 & 2.50 & 0.1450 & - & - & - & - & - \\
\hline $\mathrm{A}^{2}$ & 0.00019 & 1 & 0.00019 & 0.10 & 0.7573 & - & - & - & - & - \\
\hline $\mathrm{B}^{2}$ & 0.037 & 1 & 0.037 & 20.08 & 0.0012 & - & - & - & - & - \\
\hline $\mathrm{C}^{2}$ & 0.0015 & 1 & 0.0015 & 0.84 & 0.3813 & - & - & - & - & - \\
\hline $\begin{array}{c}\text { Lack of } \\
\text { fit }\end{array}$ & 0.018 & 0.0037 & 0.0037 & 1.87 & 0.1577 & 0.019 & 11 & 0.0017 & 2.86 & 0.003 \\
\hline \multicolumn{6}{|l|}{$\mathrm{R}^{2}=0.90$} & \multicolumn{5}{|l|}{$\mathrm{R}^{2}=0.16$} \\
\hline
\end{tabular}

A, pH; B, temperature; C, shaking speed

$* \mathrm{P}<0.05$ are significant

SS: Sum of squares; df: degree of freedom; SM: mean squares
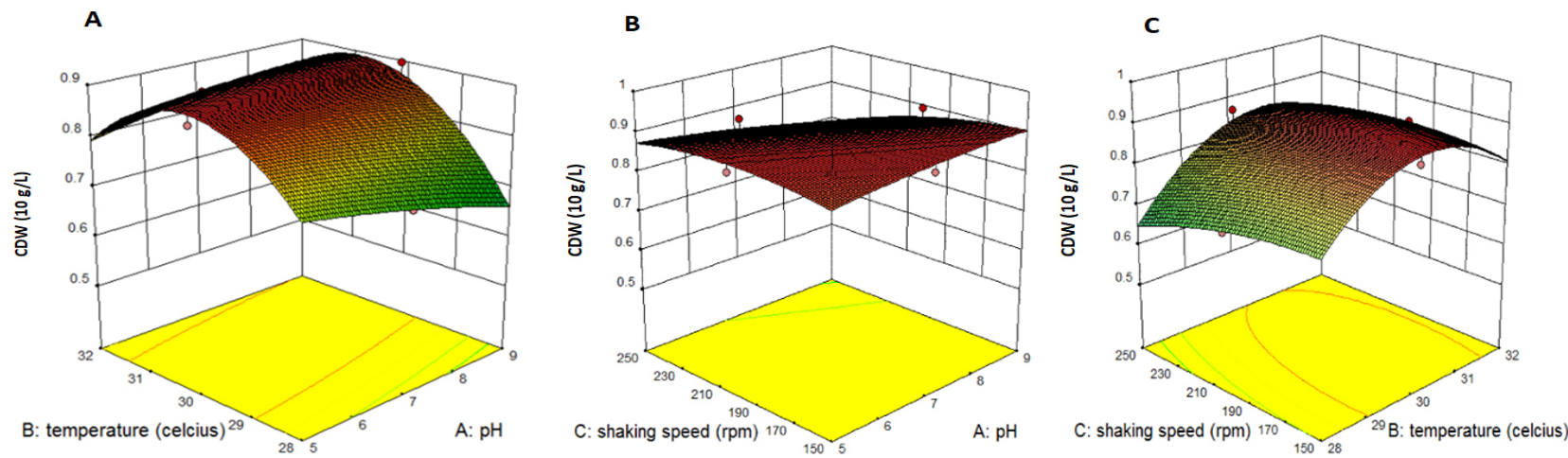

Figure 1. Response surfaces (A) A 3D Graphical combination between $\mathrm{pH}$ and temperature to the cell dry weight of Y.lipolytica TISTR 5151 (B) A 3D Graphical combination between $\mathrm{pH}$ and shaking speed to the cell dry weight of Y.lipolytica TISTR 5151 (C) A 3D Graphical combination between temperature and shaking speed to the cell dry weight of Y.lipolytica TISTR 5151.

Table 7. Validation of the optimization values predicted by RSM and the experiment

\begin{tabular}{|c|c|c|c|c|c|c|}
\hline \multirow{2}{*}{$\begin{array}{l}\text { Factor A } \\
\mathrm{pH}\end{array}$} & \multirow{2}{*}{$\begin{array}{l}\text { Factor B } \\
\text { Temperature } \\
\text { (Celsius) }\end{array}$} & \multirow{2}{*}{$\begin{array}{l}\text { Factor C } \\
\text { Shaking speed } \\
(\mathrm{rpm})\end{array}$} & \multirow{2}{*}{$\begin{array}{l}\text { Predicted } \\
\text { Cell dry } \\
\text { weight }(\mathrm{g} / \mathrm{mL})\end{array}$} & \multicolumn{3}{|c|}{ Cell dry weight from the experiment $(\mathrm{g} / \mathrm{mL})$} \\
\hline & & & & Run 1 & Run 2 & Run 3 \\
\hline 6.45 & 30 & 165 & 8.96 & 8.84 & 8.09 & 7.89 \\
\hline & & & & \multicolumn{3}{|c|}{ Average: 8.27 , Error: $7.67 \%$} \\
\hline
\end{tabular}


Table 8. Percent composition of yeast biomass and yeast protein concentrates

\begin{tabular}{cccll}
\hline Components $^{*}$ & $\begin{array}{c}\text { Y. lipolytica } \text { TISTR } \\
5151\end{array}$ & $\begin{array}{c}\text { Y. lipolytica } \text { TISTR } \\
5621\end{array}$ & \multicolumn{2}{l}{ Method } \\
\hline Total protein & 55.94 & 51.25 & AOAC 2010.AOAC official method 984.13 \\
(\%) & & & & \\
Total lipid (\%) & 0.73 & 1.54 & AOAC 2010.AOAC official method \\
& & & 2003.05 & \\
Ash (\%) & 7.43 & 6.47 & AOAC 2010.AOAC official method 942.05 \\
Total fiber (\%) & 0.61 & 0.58 & AOAC 2010.AOAC official method 962.09 \\
\hline "Percentages on a dry basis & & &
\end{tabular}

3.3 Yeast composition, amino acid, and vitamin B1 content

The biomass compositions are evaluated for two $Y$. lipolytica different strains, TISTR 5151 and 5621 . Protein concentrations of whole yeast biomass TISTR 5151 and TISTR 5621 cultured in the predicted condition were $55.94 \%$ and $51.25 \%$, respectively (Table 8). The amino acid profiles of yeast biomass in both strains are shown in Table 9. The results of amino acid content in dry yeast cells in both yeast strains were not significantly different. The high content of Lysine is found in yeast biomass (Table 9). This amino acid is essential dietary protein for the growth of catla (Catla catla), the major South Asian carp [14], and Nile tilapia $[15,16]$. Aquatic feeds for farmed fish and shrimp need each amino acid to depend on marine species [17]. Using $Y$. lipolytica dry cell in feed formulation can be an alternative approach to increase essential amino acids for aquatic feeds. Moreover, Yeast cells also contained vitamin B1 (Thiamin) as another supplement for fish feed (Table 10) [18].

Table 9. Amino acid composition analysis for the yeast biomass

\begin{tabular}{ccc}
\hline $\begin{array}{c}\text { Amino acids } \\
\text { (mg/100 g } \\
\text { protein) }\end{array}$ & $\begin{array}{c}\text { Y. lipolytica } \\
\text { TISTR 5151 }\end{array}$ & $\begin{array}{c}\text { Y. lipolytica } \\
\text { TISTR 5621 }\end{array}$ \\
\hline Alanine & 6,140 & 4,512 \\
Arginine & 2,481 & 2,532 \\
Aspartic acid & 3,782 & 4,514 \\
Cystine & 1,515 & 1,546 \\
Glutamic acid & 6,785 & 5,992 \\
Glycine & 6,765 & 4,482 \\
Histidine & 889 & 1,054 \\
Isoleucine & 1,456 & 1,861 \\
Leucine & 2,396 & 2,573 \\
Lysine & 5,347 & 4,921 \\
Methionine & 717 & 782 \\
Phenylalanine & 1,367 & 1,646 \\
Proline & 2,501 & 2,431 \\
Serine & 2,631 & 2,189 \\
Threonine & 1,813 & 2,201 \\
Tryptophan & 971 & 714 \\
Tyrosine & 1,132 & 1,221 \\
Valine & 1,689 & 2,264 \\
\hline
\end{tabular}

Table 10. Vitamin B1 analysis for the yeast biomass

\begin{tabular}{llll}
$\begin{array}{l}\text { Vitamin B1 } \\
\text { (mg/100 } \\
\text { protein) }\end{array}$ & g & $\begin{array}{l}\text { Y. lipolytica } \\
\text { TISTR 5151 } \\
1.06\end{array}$ & $\begin{array}{l}\text { Y. lipolytica } \\
\text { TISTR 5621 } \\
1.47\end{array}$ \\
\hline
\end{tabular}

\section{Conclusion}

Different $Y$. lipolytica isolates derived from Thailand Institute of Scientific and Technological Research might require various factors for maximizing yeast biomass. RSM is a powerful method for program optimization and identification of the relative significance of different factors, interactions between factors, and optimal level of test variable. The method has been successfully applied to optimize critical medium components for mycelium biomass of Lentinus squarrosulus [19], obtain the optimum temperature and drying time in making cocktail yeast molds [20], and maximize biomass of Purpureocillium lilacinum KU8 [21]. Y. lipolytica, a non-pathogenic organism, is considered as a model for a study of protein secretion, hydrophobic substrate utilization, and peroxisome biogenesis, dimorphism and mitochondrail complexI [22]. Protein, amino acid content, and vitamin B1 were found in Y. lipolytica dry cell, indicating that the dry cell yeast might be applied as a significant protein-rich ingredient in aquafeeds. Nutritional quality of Saccharomyces cerevisiae, Cyberlindnera jadinii, Kluyveromyces marxianus, Blastobotrys adeninivorans, and Wicker-hamomyces anomalus had been studied to use them as a replacement for fishmeal and soy protein in the diets of Atlantic salmon [23].

This study has been successfully optimized critical growth conditions in using molasses as a carbon source for $Y$. lipolytica varieties cultivated in Thailand. This alternative medium could reduce media cost that a significant issue for large-scale yeast cultivation.

\section{Acknowledgment}

This research was supported by the basic research funding in 2016 of Faculty of Applied Science, King Mongkut's University of Technology North Bangkok. We acknowledge Miss Mananya Thongchay and Miss Chutarat Posila for any research help 


\section{References}

1. A. Beopoulos, J. Verbeke, F. Bordes, M. Guicherd, M. Bressy, A. Marty, J.M. Nicaud, Metabolic engineering for ricinoleic acid production in the oleaginous yeast Yarrowia lipolytica, Applied Microbiology and Biotechnology, 98, 1 (2014): 251-62

2. S. Papanikolaou, G. Aggelis, Lipid production by Yarrowia lipolytica growing on industrial glycerol in a single-stage continuous culture, Bioresource Technology, 82, 1 (2002): 43-9

3. J.-M. Nicaud, Yarrowia lipolytica, Yeast, 29, 10 (2012): 409-418

4. P. Saçakl1, B.H. Koksal, A. Ergun, B. Özsoy, Usage of brewer's yeast (Saccharomyces cerevisiae) as a replacement of vitamin and trace mineral premix in broiler diets, Revue de Médecine Vétérinaire, 164, 1 (2013): 39-44

5. M.T. Pacheco, G.M. Caballero-Córdoba, V.C. Sgarbieri, Composition and nutritive value of yeast biomass and yeast protein concentrates, Journal of Nutritional Science and Vitaminology (Tokyo), 43, 6 (1997): 601-12

6. G.M. Walker, Fermentation (Industrial) : media for industrial fermentations, (E.o.f.m. editor (Ed.) Carl A. Batt. 2nd. ed. London : Academic Press,2014): 769-777

7. P. Juszczyk, W. Rymowicz, A. Kita, A. Rywińska, Biomass production by Yarrowia lipolytica yeast using waste derived from the production of ethyl esters of polyunsaturated fatty acids of flaxseed oil, Industrial Crops and Products, 138 (2019): 111590

8. M. Wróbel-Kwiatkowska, W. Turski, P. Juszczyk, A. Kita, W. Rymowicz, Improved Production of Kynurenic Acid by Yarrowia lipolytica in Media Containing Different Honeys, Sustainability, 12, 22 (2020): 9424

9. L.A. Sarabia, M.C. Ortiz, 1.12 - Response Surface Methodology (S.D. Brown, R. Tauler, B. Walczak (Eds.), Comprehensive Chemometrics, Elsevier, Oxford, (2009): 345-390

10. E. Li, R. Mira de Orduña Heidinger, A rapid method for the determination of microbial biomass by dry weight using a moisture analyser with an infrared heating source and an analytical balance, Letters in applied microbiology, 50 (2010): 283-8

11. P. Herbert, P. Barros, N. Ratola, A. Alves, HPLC Determination of Amino Acids in Musts and Port Wine Using OPA/FMOC Derivatives, Journal of Food Science, 65, 7 (2000): 1130-1133

12. F. Batifoulier, M.A. Verny, E. Chanliaud, C. Rémésy, C. Demigné, Effect of different breadmaking methods on thiamine, riboflavin and pyridoxine contents of wheat bread, Journal of Cereal Science, 42, 1 (2005): 101-108

13. S. Hackenschmidt, F. Bracharz, R. Daniel, A. Thürmer, S. Bruder, J. Kabisch, Effects of a high- cultivation temperature on the physiology of three different Yarrowia lipolytica strains, FEMS Yeast Research, 19, 7 (2019): 31605534

14. J. Ravi, K.V. Devaraj, Quantitative essential amino acid requirements for growth of catla, Catla catla (Hamilton), Aquaculture, 96, 3 (1991): 281-291

15. C.B. Santiago, R.T. Lovell, Amino Acid Requirements for Growth of Nile Tilapia, The Journal of Nutrition, 118, 12 (1988): 1540-1546

16. R.d.S. Romaneli, do Nascimento, T. Matias Torres, Gous, R. Mervyn, Reis, M. de Paula, Mansano, C. Fernando Menegasso, Khan, K. Ullah, Sakomura, N. Kazue, \& Fernandes, J. Batista Kochenborger., Response of Nile tilapia (Oreochromis niloticus) to lysine: Performance, body composition, maintenance and efficiency of utilization, Aquaculture, 538 (2021): 736522

17. A.J.P. Nunes, M.V.C. Sá, C.L. Browdy, M. Vazquez-Anon, Practical supplementation of shrimp and fish feeds with crystalline amino acids, Aquaculture, 431 (2014): 20-27

18. F.G. Laura Gasco, G. Maricchiolo, L. Genovese, S. Ragonese, T. Bottari, G. Caruso, Supplementation of Vitamins, Minerals, Enzymes and Antioxidants (Feeds for the Aquaculture Sector. SpringerBriefs in Molecular Science. Springer, Cham, 2018): 63103

19. R. Ahmad, N.K.N. Al-Shorgani, A.A. Hamid, W.M.W. Yusoff, F. Daud, Optimization of medium components using response surface methodology (RSM) for mycelium biomass and exopolysaccharide production by Lentinus squarrosulus, Advances in Bioscience and Biotechnology, 4, 12 (2013): 1079-1085

20. R. Rahmawati, Hunaefi, D., Basriman, I., Saputra, D., Apriliani, A.A. and Jenie, B.S.L., Optimization of temperature and drying time of indigenous cocktail yeast mold culture using response surface methodology (RSM), Food Research, 4, 2 (2020): 389 - 395

21. M. Mousumi Das, M. Haridas, A. Sabu, Process development for the enhanced production of bionematicide Purpureocillium lilacinum KU8 under solid-state fermentation, Bioresource Technology, 308 (2020): 123328

22. J.M. Nicaud, Yarrowia lipolytica, Yeast, 29, 10 (2012): 409-418

23. J.O. Agboola, M. Øverland, A. Skrede, J.Ø. Hansen, Yeast as major protein-rich ingredient in aquafeeds: a review of the implications for aquaculture production, Reviews in Aquaculture, 13, 2 (2021): 949-970 